\title{
1. Pathways to a Free Trade Area of the Asia Pacific: problems and prospects
}

\author{
Peter C.Y. Chow*
}

\subsection{INTRODUCTION}

The forging of the Trans-Pacific Partnership (TPP) in October 2015 was a major milestone, if seen as part of a continuum towards deepening regional economic integration; and possibly a watershed, if seen to have altered the path in the evolution of Asia Pacific regionalism. The future is always opaque, yet certain seeds have been planted. This book explores the TPP's implications for the future architecture of the Asia Pacific economic region.

\section{Vision and Reality}

The vision of economic regionalism in the Asia Pacific has rarely been concordant with the reality. General peace and the conditions for regional economic development in East Asia emerged only in the 1980s, following China's historic opening up in the post-Mao era. Up to that point, economic relations in the Asia Pacific featured a hub-and-spoke pattern, with the regional hegemonic power, the United States (US), as the hub, and the East Asian economies as the spokes.

The first major change in this pattern followed the steep appreciation of the Japanese yen as a result of the Plaza Accord of 1985, which sharply expanded the practice by Japanese firms to outsource labor-intensive production. ${ }^{1}$ Their major destination was initially Southeast Asia. The flow of Japanese foreign direct investment (FDI) into the underdeveloped economies of Southeast Asia triggered the "Asian Miracle" boom and gave rise to the emergence of regional value chains.

Alongside this very real business-driven production regionalization in East Asia was the largely fictitious policy-driven regionalization under the aegis of the Association of Southeast Asian Nations (ASEAN). 
The ASEAN Free Trade Agreement (AFTA) was the first major FTA signed in the region, bringing together the six economies of Brunei, Indonesia, Malaysia, the Philippines, Singapore, and Thailand. It subsequently expanded through the accession of the so-called CLMV group of Cambodia, Laos, Myanmar, and Vietnam. The AFTA had little liberalizing impact, since trade in the main regional products was not liberalized and trade relations were not significantly deepened; it did, however, serve as a confidence-building exercise and created a platform for future regional integration.

The second major impetus to East Asian economic regionalization came from China. In the wake of China's post-Tiananmen Square economic slump, Deng Xiao Ping made his famous southern tour in 1992, which led to the launch of the market-oriented reforms that made China a new magnet for FDI globally, including from the more advanced East Asian regional economies: Japan, Hong Kong, Korea, Singapore, and Taiwan.

Alongside this dynamic business-driven regional development was another largely fictitious policy-driven regionalization, this time under the aegis of the Asia-Pacific Economic Cooperation (APEC) forum. APEC was established in 1989, in part due to Australia's fear of marginalization under various competing visions for regional economic integration, which were floated to capture the momentum of regionalization then under way and which included Malaysian Prime Minister Mahathir's proposal for an East Asian Economic Caucus. The ideas of Asia Pacific free trade (in 1993 under the US chairmanship of APEC) and of the 1994 Bogor goals of free and open trade in the Asia Pacific by 2010 for developed members and 2020 for less-developed members were then floated (APEC, 1994). APEC's attempt to operationalize this, in the form of the Early Voluntary Sectoral Liberalization (EVSL) program adopted during Canada's chairmanship in 1997, flopped and the program was quietly shelved by folding it into ongoing Geneva negotiations.

\section{The Game-Changing Events}

The Asian Economic and Financial Crisis of 1997, China's 2001 accession to the World Trade Organization (WTO), and the collapse of the WTO's Doha Round of trade negotiations were game-changing events for East Asian regionalization, altering its path and prospects irrevocably. The devastating impact on East Asian economies of the sudden reversal of capital flows that had fueled the Asian Miracle boom, coupled with the mishandling of the crisis by the International Monetary Fund (IMF), which imposed measures that intensified the crisis (the infamous "IMF conditionality"), resulted in divergent interpretations of the cause. In 
East Asia, the crisis became known as the "IMF Crisis"; in the West, it was chalked up to Asian "crony capitalism." New East Asian economic cooperation initiatives emerged, such as the Chiang Mai pact for regional cooperation on exchange rate management. These did not include the United States and were formed outside the framework of the existing international institutions.

China's WTO accession together with its FDI-induced export growth, meanwhile, triggered a boom that saw China emerge as an economic powerhouse. Its export-led growth allowed it to accumulate vast foreign currency reserves that set the stage for Chinese outward FDI, which was also motivated by an accelerated appreciation of the renminbi, as nominal exchange rate appreciation overtook real exchange rate appreciation driven by rising internal prices and wages starting in 2005 .

The stalling of the WTO negotiations in the Doha Round, marked by the failure of the WTO Ministerial in 2003 in Cancún, triggered a new global phenomenon to which East Asia was an active party: the proliferation of preferential trade agreements. The discriminatory nature of these agreements, in turn, triggered a domino effect as excluded parties scrambled to re-level the playing field in key export markets.

Two sets of these new FTAs loom large in retrospect: the set of agreements forged by ASEAN with Australia and New Zealand, China, India, Japan, and Korea (ASEAN+1 agreements); and the Trans-Pacific Strategic Economic Partnership Agreement, or P4. The former set the stage for the launch of the Regional Comprehensive Economic Partnership (RCEP) negotiations, while the latter culminated in the TPP.

\section{ASEAN-Led Regional Initiatives}

The five ASEAN+1 FTAs entered into force between 2005 and 2010 . They follow no common template: the depth of liberalization varies and the architecture of the agreements ranges from relatively comprehensive FTAs, such as the ASEAN-Australia-New Zealand FTA (AANZFTA), to framework agreements under which a series of separate agreements on goods, services, and other issues are negotiated (for example, the ASEAN-Japan model). Alongside these agreements, individual members of ASEAN have concluded agreements of their own, including with both ASEAN + 1 partners and others: for example, Singapore has entered into FTAs with China, as well as the United States. The result is a veritable "noodle bowl" of overlapping, inconsistent FTAs and economic partnership agreements (EPAs), with varying liberalization schedules, exclusions, and coverage of non-core trade issues.

The underutilization of these FTAs - in good part due to the complexity 
and inconsistency of the rules of origin (ROOs) for accessing the preferences created by these agreements - led to calls for regionalizing the various ASEAN +1 agreements. Specific initiatives proposed and formally studied were the ASEAN+3 (China, Japan, and Korea) initiative for an East Asia Free Trade Area (EAFTA) and the ASEAN +6 (adding Australia, New Zealand, and India to the ASEAN+3) initiative for a Comprehensive Economic Partnership in East Asia (CEPEA). The RCEP is the direct successor to the CEPEA process, building on recommendations that regionalization of the ASEAN+1 agreements would bring significant economic benefits.

The RCEP Framework was adopted at the 19th ASEAN Summit in Bali in November 2011. The Guiding Principles and Objectives for Negotiating the RCEP were adopted by the Ministers at the 1st ASEAN Economic Ministers (AEM) Plus ASEAN FTA Partners Consultations on August 30, 2012 in Siem Reap, Cambodia, and endorsed by leaders at the launch of the RCEP negotiations on the margins of the 21st ASEAN Summit on November 20, 2012 in Phnom Penh, Cambodia. In the November 20, 2012 Joint Declaration on the Launch of Negotiations for the RCEP, leaders committed to negotiations towards a modern, comprehensive, high-quality, and mutually beneficial EPA to be completed by the end of 2015. The initial terms of reference for the RCEP Trade Negotiating Committee were established by leaders on February 26-28, 2013 in Bali, Indonesia, and have since been expanded to cover new subject areas.

In parallel with the RCEP negotiations, individual parties to this negotiation have separately struck new agreements that contribute to completing the network of bilateral agreements within the group. These include the Australia-Korea FTA, which follows a modern, comprehensive template; and the Australia-China FTA, which does not. Moreover, in parallel with the RCEP, ASEAN is pursuing still deeper regional integration by seeking to form a single market through the ASEAN Economic Community (AEC) initiative, which is to be formally completed at the same time as the RCEP.

The RCEP is a bottom-up process, with negotiators gradually feeling their way towards achievements. Relatively few bilateral relationships remain to be liberalized, but there is still much room for deepening commitments and for converging towards a common template, as well as for trade gains from regionalization of the ROOs. Insofar as "architecture" is concerned, what emerges in the RCEP will be discovered, not imposed, as it includes countries at very different levels of development: there are high-income countries, such as Australia, Brunei, Japan, Korea, New Zealand, and Singapore; middleincome countries, such as China, India, Indonesia, Malaysia, and Thailand; and low-income countries in the CLMV group (Cambodia, Laos, Myanmar, 
and Vietnam). The RCEP will, thus, more narrowly focus on trade liberalization in goods and for development among its members, especially in those low-income countries, with more limited undertakings regarding market access in services trade, ${ }^{2}$ and will likely not tackle contentious behind-theborder governance issues in such areas as competition and state-owned enterprises (SOEs), anticorruption, or labor and environment standards.

\section{Trans-Pacific Regionalization}

The P4 process that culminated in the TPP was quite different. This agreement had deep roots that go back to discussions in the 1990s through which the United States, Australia, Singapore, Chile, and New Zealand explored a new type of trade agreement among like-minded states. Since Australia and the United States declined to proceed to formal negotiations, Chile, New Zealand, and Singapore launched the initiative on their own at the 2002 APEC Leaders meeting in Mexico (Elms and Lim, 2012), with Brunei Darussalam joining in some time later. ${ }^{3}$ The little-noted agreement between these four small and already highly open economies came into force in 2006. Given the limited amount of trade amongst the four parties, they fully recognized the very limited commercial potential of this original deal. The major purposes of the agreement were, in fact, to establish a benchmark for trade liberalization, to create a demonstration effect for the WTO, and to serve as a platform to which other countries could accede. ${ }^{4}$

As notified to the WTO in 2006, the P4 liberalized 100 percent of trade and tariff lines for Chile, New Zealand, and Singapore, and more than 99 percent for Brunei Darussalam. Measures governing trade in services are framed in a "negative list" approach, and significantly expand on the parties' General Agreement on Trade in Services (GATS) commitments. ${ }^{5}$ The original P4 also included chapters on customs, sanitary, and phytosanitary (SPS) measures and technical barriers to trade (TBT) (including cooperation), competition policy, intellectual property (IP), government procurement, temporary entry of business persons, and dispute settlement; additionally, a strategic partnership chapter covered cooperation in such fields as education, primary industry, culture, and science and technology. A Memorandum of Understanding (MOU) on labor cooperation and an Environment Cooperation Agreement were concluded in conjunction with the agreement. ${ }^{6}$

The extent to which the P4 lived up to its billing of setting a new standard for trade agreements has been challenged. Several criteria have been suggested against which to assess this claim, and the P4 has been found lacking in a number of areas, including the following: 
- Relatively complicated and restrictive ROOs. ${ }^{7}$

- Less coverage in services liberalization than in some of the other FTAs signed by the various parties (although it does meet two other criteria for a high-quality agreement, namely the "third party" most-favored nation, MFN, clause and "leaky" or liberal ROOs for services providers). ${ }^{8}$

- Lesser commitments on government procurement than the AANZAFTA (Capling, 2009).

- Failure to exclude or restrict use of trade remedies on intra-FTA trade. ${ }^{9}$

- Different levels of commitments amongst the parties, following a pattern consistent with the extent of liberalization: that is, lower commitments by parties with market power (which Gao, 2009, sees as a bad portent for expansion of the agreement to more powerful countries).

- Failure to rationalize existing agreements and streamline rules into one set, thus adding to, rather than untangling, the noodle bowl of overlapping FTA deals (Elms, 2009).

Notwithstanding these issues, the $\mathrm{P} 4$ did succeed in its main aim, which was to establish a platform for accession. The announcement by the United States in September 2008 of its intention to join the negotiations prompted Australia, Peru, and Vietnam to follow suit during the following APEC Summit in November 2008 in Lima. On November 14, 2009, US President Obama announced that the eight countries would seek to establish a regional agreement with broad membership and the highest standards. Thus was born the TPP, with the negotiating group subsequently expanding to include Malaysia, Canada, Mexico, and Japan.

Unlike the RCEP, the TPP was born with architecture in mind, and the main negotiating challenge was how to carve out the necessary derogations to permit such countries as Vietnam, whose economic policy frameworks were far from compatible with the TPP template, to participate in the agreement. The agreement that was agreed to in October 2015 was, thus, a pre-conceived model with derogations, the general idea being that over time these derogations would fall away, leaving in place the conceptual model. Thus, alongside its 30 chapters, it includes a large number of annexes, bilateral letters, and side agreements that introduce commitments that could not be agreed within the negotiating group as a whole.

Like other recent comprehensive agreements, the TPP goes beyond reduction of barriers to investment and to trade in goods and services (dealing, inter alia, with tariffs, ROOs, customs administration, SPS measures, TBT, trade remedies, and with investor-state dispute settlement, ISDS ${ }^{10}$ ), and 
includes now-standard chapters on IP, government procurement, movement of business persons, electronic commerce, transparency, dispute settlement, and institutional measures related to the implementation of the agreement. However, it also addresses numerous "horizontal" issues that impact on the business climate, including competition and disciplines on SOEs and designated monopolies designed to impose "competitive neutrality" with private competitors; core labor standards; environmental measures; economic development; competitiveness and business facilitation; small and medium-sized enterprises (SMEs); regional supply chains and regulatory coherence; and anticorruption. Issues regarding currency manipulation could not be settled, but it was addressed in a side agreement between the United States and Japan. The agreement also sets up a TPP Commission to oversee the work of the various working groups and committees that are to be formed under the agreement.

Hence, if the TPP is implemented as negotiated, it will not only be "WTO-plus" in terms of deepening commitments that are already addressed under the WTO Agreement, but also "WTO-extra" by venturing into new areas that the WTO Agreement does not address. In that regard, one can anticipate that developing countries will probably be more interested in joining the RCEP, whereas developed countries may be more interested in the TPP.

In essence, one can conclude that the TPP has three major dimensions: the now-standard chapters addressing trade and investment and directly related issues; a range of non-binding cooperative measures and mechanisms aimed at regional integration; and behind-the-border governance issues concerning competition, labor, and the environment. How these measures will affect international trade (for example, by ostensibly "leveling the playing field," as the core labor standards chapter explicitly targets, or by deepening regional value chains and other economic linkages) is as yet unclear. Nor is it clear how effective the TPP will be in inducing governments to enforce multilateral environmental agreements (MEAs) such as those dealing with trade in endangered species and in illegal fishing, two issues addressed at length in the TPP, or other serious environmental issues such as illegal logging and cutting greenhouse gas emissions, on which the TPP is conspicuously silent. While the TPP clearly fell short of realizing its ambitions in many areas - the chapter on core labor standards, for example, which covers standards set by the International Labour Organization regarding freedom of association, collective bargaining, forced labor, prohibition of child labor, and discrimination in employment, narrowly targets Brunei, Malaysia, and Vietnam, rather than setting more general requirements - it signals the future direction of international economic governance. 


\section{An Age of Possibilities and Uncertainties Dawns}

The shift of regional integration efforts to the mega-regional negotiations has clearly left APEC on the sidelines. With the Bogor goals of free and open trade and investment in the Asia Pacific not having been met, the APEC Economic Leaders Meeting in 2010 reaffirmed the long-term goal towards the realization of a Free Trade Area of the Asia Pacific (FTAAP) and repositioned APEC as an incubator. ${ }^{11}$ During the APEC meetings in Beijing in 2014, it was reconfirmed that both the RCEP and TPP would be seen as potential pathways towards an FTAAP. ${ }^{12}$ However, what such an FTAAP would look like, having been through this evolutionary process, remains very much to be defined; furthermore, the role that APEC will play in this is still unclear.

There are, of course, no done deals yet. The TPP must pass the ratification process in at least six countries with an aggregate gross domestic product (GDP) totaling at least 85 percent of the group's total GDP to come into force. That may not be easy.

In the United States, for example, the Obama administration obtained Trade Promotion Authority (TPA) only with the greatest difficulty. It is reasonable to presume that the administration has little flexibility in presenting Congress with something that will require compromises to those undertakings made to secure the TPA. Whether the TPP as negotiated passes that test remains to be seen. The Obama administration must convince Congress that it is a crucial ingredient for the US strategic pivot to Asia (Cheng and Chow, 2014); it is likely that it will expend all of its political capital to do so, as it could be one of the most important legacies for Obama on trade policy.

In Canada, a change of government in November 2015 brings new uncertainty to ratification; in particular, because the new Trudeau government is restoring parliamentary authority after three terms during which decision-making was centralized in the Prime Minister's Office under Stephen Harper. The rubber stamp that was assured under Harper is no more. In Japan, 2016 is an election year for the House of Councilors, the Upper House of the Japanese Diet; with half of the 242 Councilors facing re-election, the TPP's agricultural concessions could be a political bone of contention (Harris, 2015).

As for the RCEP, although it remains to be inked, the domino theory logic suggests that the TPP signing will put pressure on the RCEP's nonTPP members to reach a deal to safeguard their market position in the TPP members' economies. China, in particular, may feel the pressure to underwrite an ambitious outcome to sustain its ambitions regarding leadership in the region. 
Computable general equilibrium (CGE) model simulations by Petri et al. (2011 [2013]) show significant trade diversion effects for non-member countries from both trade blocs. For example, as a TPP outsider, Indonesia will lose 0.14 percent of GDP relative to its baseline, the Philippines 0.24 percent, Taiwan 0.12 percent, and Thailand 0.44 percent. Thus, these countries have a strong economic incentive to join the TPP. Among them, Taiwan, which is not involved in either the TPP or the RCEP, will suffer a 1.92 percent GDP loss relative to baseline. On the other hand, Hsu (2013) shows that all TPP members, except for Peru, would benefit from Taiwan joining the TPP, while Taiwan itself would boost its GDP by 1.1 percent. In Chapter 4 in this book, Ciuriak and Xiao, using updated CGE modeling, show similar effects of Taiwan's accession to the TPP.

The implications for Asia Pacific regionalism of both deals are far from clear. Since the current tariffs and non-tariff barriers (NTBs) are higher in most RCEP countries than in TPP countries, the benefits of trade liberalization among the former will be greater than among the latter (Petri et al., 2011 [2013]; Hsu, 2013). However, as Chow and Hsu show in Chapter 7 in this book, model simulations suggest that, if the TPP achieves a 25 percent reduction of NTBs to services trade, then its benefits will be greater than RCEP's.

In terms of progressing towards the APEC goal of free and open trade in the Asia Pacific, the TPP fell short, as it was unable to break the power of the main agricultural protectionist lobbies in the region - sugar in the United States, rice in Japan, and dairy in Canada - which are faced with only marginal concessions and compensated with large subsidies. The highly protected light trucks market in the United States will be liberalized, but not within today's business and political decision-makers' lifetimes and, possibly, given the pace of technological change, not even within light trucks' lifetime. The TPP also did little to liberalize services markets; its main impact was instead to bind existing market access. FDI was already largely untrammeled except in a limited number of sensitive sectors; thus, the additional liberalization is commensurately relatively modest. Accordingly, the TPP promises a fairly heavy undertaking in terms of rules commitments, including in such areas as IP, which represent potential costs for acceding parties in return for relatively little in the way of additional market access. While it is attractive to non-parties facing trade diversion, this attractiveness is likely to be less than that of the TPP as it was anticipated. Put another way, the TPP is likely to expand, but it is an open question as to whether it will have sufficient trade cachet to pull in the entire Asia Pacific. This is an especially important consideration given that most of the Asia Pacific economies that are not in the TPP are developing economies that need agricultural market access. 
Where the TPP failed, the RCEP is not likely to succeed; and where the TPP succeeded - in driving a significant increase in IP protection - the RCEP does not wish to go. While there are advantages to being the first mover, there are also advantages to second movers from the knowledge spillovers flowing from the pioneers. Armed with the TPP textbook, RCEP negotiators can zero-in on necessary compromises that the TPP has defined as the state of the art (of the feasible).

This book investigates the questions surrounding the future of Asia Pacific regionalism in view of the historic TPP agreement and of the continuing RCEP negotiations. The remainder of the present chapter is organized as follows. Section 1.2 assesses the implications of the emergence of competing blocs and economic models. Section 1.3 charts alternative pathways towards an FTAAP to reconcile these inter-bloc tensions. Section 1.4 previews this book's contributions to our understanding of the mega-regionals' problems and prospects in the Asia Pacific. Section 1.5 briefly concludes.

\subsection{COMPETING BLOCS?}

The two mega blocs of the TPP and the RCEP are likely to be put in place in the near future. They will create a bipolar model of economic integration, led by the two major regional economic powers, the United States and China. ${ }^{13}$ The differing priorities of these leading economies will affect the path each bloc takes in terms of liberalization and rules setting: "By assuming leadership, an economy can set a favorable agenda and establish convenient rules. In addition, the most powerful state can increase influence through prestige and asymmetric economic interdependence with others" (Hamanaka, 2014).

In geopolitical terms, both the TPP and the RCEP have important implications for the Asia Pacific power structure; Cheng and Chow (2014) argue that the TPP is an integrated strategy of the United States' "pivot to Asia," which aims to safeguard its regional economic and security interests. On the other hand, the RCEP is more than a trade pact for China to integrate with the Asia Pacific economies; it is also an instrument for Beijing to enhance China's leadership in the Asia Pacific. The emerging trade blocs' development will not only significantly affect the trade regime landscape, but will also inevitably alter the power structure in the Asia Pacific. In geo-economic terms, the path to regional integration will be shaped by the nature and scale of the challenges that each bloc faces. If the European Union's experience is any guide, the path to enlargement will be easier than the path to deepening.

The TPP's complex liberalization schedules and the often-extended timeframes for conformity with its measures suggest that further deepening of 
commitments will most likely be incremental and gradual. Quite apart from achieving ratification, implementation will be the TPP's next major challenge, especially in the difficult new areas. Its built-in timetables to review implementation and effectiveness are likely to impose considerable demands on the responsible officials. The RCEP's challenge in terms of digesting the terms of the agreement is unlikely to be as great, but it will have a larger challenge in bringing along the least-developed members of the group through the cooperation mechanisms that it is likely to contain, and in obtaining commitments from India, which is likely to be the most difficult partner in the group.

For both blocs, enlargement will seem easy in comparison to achieving full implementation, let alone further deepening. This "path of least resistance" aspect will be reinforced by the bloc leaders' motivation to enhance their regional spheres of influence. For third parties, damage control related to their eroded competitive position within the blocs will dominate. Ciuriak (2010: 1) argues that, "once a critical mass of intraEast Asian trade is brought under preferential regimes, the pressure for a region-wide participation could well become irresistible - in short a domino effect could take off within the region." The larger the negative effect on the outsider is, the greater its incentive will be to join.

The driving force for this membership enlargement will thus come from both inside and outside the blocs. The timing and sequencing of the expansion of each trade bloc will be different because of membership criteria and priorities in each trade pact. It is also important to bear in mind that rapid expansion may not happen: as Schott et al. (2013: 50-51) observe, FTA accession clauses have been used only rarely.

The RCEP's priority is to consolidate the five ASEAN +1 agreements by liberalizing the currently non-liberalized bilateral relationships and, equally importantly, by regionalizing the ROOs to allow genuine regional integration. The RCEP will have an open accession clause pursuant to its guiding principles, but the idea of member recruitment has been given comparatively little prominence to date, despite the continuous prospect of Hong Kong and Taiwan joining, which has simmered quietly on the backburner.

Clearly, for the RCEP to serve as the basis for an Asia Pacific trade arrangement, it has to expand east to include the Americas. A logical first step would be to amalgamate itself with the Pacific Alliance, which includes three APEC members, as well as Colombia, which itself has TPP aspirations. A second would be to court Canada, which beat the United States to the punch in striking a deal with the European Union and may want to attempt a repeat in the Asia Pacific.

The TPP also includes an accession clause to permit "like-minded" APEC members to join in after its conclusion. ${ }^{14}$ In the Ministers' Report 
to leaders, the United States Trade Representative (USTR) reaffirmed this commitment, saying that, "we have continued to engage with economies that have expressed interest in joining TPP in the future" (USTR, 2014). Nevertheless, there is a "double eligibility criteria," which requires new members to be approved by individual incumbents as well as by the group.

Currently, there are nine APEC members that do not belong to the TPP: China, Hong Kong, Indonesia, Korea, Papua New Guinea, the Philippines, Russia, Taiwan, and Thailand. Unlike the RCEP, there has been widespread and active discussion of new entrants. In particular, Korea, Indonesia, the Philippines, Taiwan, and Thailand have all expressed interest in joining and have, indeed, reiterated their interest since the deal was reached.

China has also been studying TPP membership. As much as the United States becoming an ASEAN+1 partner would change the RCEP dynamic, so would China joining the TPP. Though the United States has repeatedly assured China that the TPP's high standard is not intended to exclude any APEC member, including China, Beijing may have different perceptions. Zhang (2014) discusses how far away China is from the TPP in various economic aspects. Cheng and Lee analyze China's attitude towards the TPP in Chapter 3 of this book.

As regards the other potential APEC entrants, Korea is best placed to join the TPP, because it has signed FTAs with almost all the members. ${ }^{15}$ Hong Kong's membership, on the other hand, probably has to wait till China decides whether or not to join the TPP; while Papua New Guinea is not actively pursuing regional economic integration. Russia, although it has an FTA with India, is more interested in the Eurasian Economic Community (EurAseEC). ${ }^{16}$ In the end, the likely APEC members to join the TPP after Korea, are Indonesia, the Philippines, Taiwan, and Thailand. The relative contributions of these four countries to the US economy are addressed in Chapter 5 in this book by Chow.

From the above analysis, the idea that Asia Pacific regionalism is likely to proceed on a two-speed basis - broadening faster in the RCEP bloc because of its lesser policy commitments, and deepening faster in the TPP bloc because of its rules-related ambitions - is reversed: the TPP is more likely to see significant expansion, while the RCEP is more likely to have time to deepen before it broadens; and when it broadens, it is likely to go in quite different directions than absorbing additional APEC members.

The trade and investment regimes that emerge under these two blocs will be somewhat different, but far from mutually exclusive. The regimes will be anchored in a generally compatible zone by the dual memberships of Australia, Brunei, Japan, Malaysia, New Zealand, Singapore, and Vietnam. This may serve to reduce tensions between the two blocs, as the common members have a great incentive to harmonize the trade rules and, 
thus, maximize the benefits of joint participation. The RCEP is, therefore, likely to resemble the TPP where they overlap, while other areas will be "TPP-minus" to accommodate non-TPP parties that are not prepared to accept the full range of TPP undertakings.

\subsection{ALTERNATIVE TRACKS TOWARDS FREE TRADE IN THE ASIA PACIFIC}

For over two decades, the Asia Pacific has embraced the long-term objective of free and open trade. How will the formation of mega trade blocs affect the potential to realize this idealized trade regime? Conceptually, one can identify various pathways to the FTAAP under APEC's framework:

1. the TPP expands to forge a region-wide FTAAP (TPP $\rightarrow$ FTAAP);

2. the RCEP expands to forge a region-wide FTAAP (RCEP $\rightarrow$ FTAAP);

3. a merger or consolidation of the TPP and RCEP (TPP + RCEP $\rightarrow$ FTAAP);

4. a new FTAAP negotiation; or

5. the mega trade blocs remain, while the FTAAP continues to be the long-term objective.

Whether the two mega trade blocs will be parallel, merge, or harmonize to consolidate into a unified region-wide free trade system depends on the enlargement of their respective memberships, expanding sectoral liberalization and policy measures undertaken by the constituents, especially the leading countries in each camp. ${ }^{17}$

Unlike Petri et al. (2011 [2013]), which sets 2020 as the anticipated date for RCEP-TPP consolidation, this chapter makes no speculation on the timing of the eventual outcome and only assesses the likelihood of each possible scenario emerging within the next decade or so. Without normative judgment, one can assess the likelihood of each scenario and the feasibility of each pathway towards a region-wide free trade regime. Among these five scenarios, it seems that competitive trade liberalization within each bloc, promoted by expanding memberships, with the FTAAP remaining as a long-term goal, is the most likely scenario for the near future.

\section{Scenario 1: The TPP Expands to Forge a Region-Wide FTAAP (TPP $\rightarrow$ FTAAP)}

The TPP clearly has the inside track in serving as the base for an APECwide FTAAP, for several reasons. First, an agreement has already been 
signed and, while ratification and implementation issues undoubtedly will not be easy, 12 of the 21 APEC members are involved.

Second, as stated, at least four APEC members, whose entry into the TPP would not be problematic on geopolitical grounds, have already signaled their intent to join: Indonesia, Korea, the Philippines, and Thailand. This would bring the count to 16, representing a sizeable quorum of APEC members. Since they have been studying accession for some time and reiterated their interest after the deal was published, it can be presumed that their internal calculations have taken into account the domestic hurdles to participation. What remains to be seen is whether the incumbent parties will raise the entry price sufficiently high in terms of demands for market access to applicants' markets, while denying market access to their own sensitive sectors, causing new applicants to walk away. As Ciuriak and Xiao show in Chapter 4 in this book, TPP outsiders will benefit by joining, but incumbents will see their newly gained preferences from the TPP eroded. The greatest resistance to expansion is, thus, likely to come from inside, though it may not be sufficient to prevent expansion under pressure from applicants and, most likely, from the United States.

Third, of the remaining five APEC members outside the fold, two (Russia and Papua New Guinea) are not likely to join in the foreseeable future, which boils down the task of forging an FTAAP on a TPP basis to negotiating the entry of China, Hong Kong, and Taiwan. Taiwan is keen to join (Ciuriak and Xiao document their case in Chapter 4), while Hong Kong is taking a "wait and see" stance: its Chief Executive has clearly outlined Hong Kong's trade priorities, which are, in order, the Comprehensive Economic Partnership Agreement with China (Hong Kong's major trading partner), the Trade in Services Agreement (TiSA) negotiations (which include eight of Hong Kong's ten largest services export markets), the ASEAN-Hong Kong FTA, and the RCEP. China, meanwhile, has actively studied the implications of joining, but has made no firm declaration of intent, preferring instead to advance alternative options, such as an APEC-led FTA initiative. China's prospective participation is addressed in Chapter 3 in this book. Given issues of saving face, this scenario may depend much more on diplomacy - and potentially APEC, in some sense, taking ownership of the TPP - than on the accession terms themselves.

In terms of rules, the TPP would likely remain much as it is. The dynamic elements of the agreement in terms of the TPP Commission's role and the engagement in regulatory coherence exercises have potentially wide-ranging impacts. While this remains to be proven, it would likely evolve gradually. On product coverage, expanding the TPP is likely to 
involve the same difficult negotiations on sensitive agricultural sectors as the original negotiation; and is likely to disappoint as much as the original negotiation did.

\section{Scenario 2: The RCEP Expands to Forge a Region-Wide FTAAP $(\mathrm{RCEP} \rightarrow$ FTAAP)}

The RCEP is less well positioned to serve as the basis for an FTAAP for two reasons: first, although seven TPP members are also TPP parties, the RCEP excludes all other trans-Pacific economies; and second, it includes India and a number of less-developed non-APEC member economies that are not ready to accept the disciplines of the TPP. Indeed, India will make it difficult to negotiate the RCEP, in the first place, and it would be impossible to negotiate its entry to the TPP, now or in the foreseeable future. Accordingly, an RCEP-based expanding free trade zone would not resemble a TPP-based one, which could result in an FTAAP.

An RCEP-based expansion path would, undoubtedly, run first through Hong Kong and Taiwan. Then it would have to target the most free-tradeoriented economies in the Americas, these being, in order, Canada, Chile, and Peru. An ASEAN+1 agreement with each would establish their eligibility to dock with RCEP. Canada has long been in FTA negotiations with India and has made tentative steps towards a trade deal with China. Chile and Peru would not represent difficulties for the RCEP.

This leaves Mexico and the United States. Mexico was the most difficult WTO member for China to deal with on its WTO accession negotiations and would likely take up that mantle again with its APEC accession. The difficulties of negotiating a Mexico-India pact would likely be similarly difficult.

The United States would not join a China-led club. Accordingly, a political framework that currently does not exist would have to be formed. The simplest route would be for APEC to welcome India and the remaining ASEAN members into its community, as discussed in the next subsection. This would enable APEC to take ownership of RCEP - much as it would have to take ownership of the TPP on the alternative track sketched out in Scenario 1 - to permit the production of an FTAAP that includes the two giants.

On product coverage and sector liberalization, this scenario would likely result in shallower commitments than Scenario 1. The final step of including the United States, which would likely make tough demands on agricultural market access and IP rights, could be insurmountable for India in particular. Conversely, it would be problematic for the US Senate to ratify any trade accord without liberalizing these agricultural products, 
because all US senators have constituents of farmers and ranchers in their home states. ${ }^{18}$

Therefore, this scenario is highly problematic, as it must be preceded by the difficult conclusion of the RCEP itself. As Menon (2014: 6) points out, "Unless there is enough political will to close potential loopholes disguised as flexibility and pursue reforms deeper than those ever before attempted, RCEP's future as a consolidated bloc remains uncertain."

\section{Scenario 3: A Merger or Consolidation of the TPP and RCEP $(\mathrm{TPP}+\mathrm{RCEP} \rightarrow$ FTAAP $)$}

Can these two trade blocs converge to form the FTAAP? As the TPP and the RCEP have different standards of trade liberalization, if they merge, the first question is: which standard to apply? A multi-speed merger would be required. This should not be a problem. For example, in the TPP, the US liberalization schedule for Vietnam is much slower than for other members, and Vietnam, in turn, gets longer periods for compliance with particular measures that others parties must adopt on entry into force.

Also, some RCEP states would negotiate derogations from TPP requirements, just as some current TPP parties obtained derogations from otherwise common provisions as part of the deal-making to reach agreement on the TPP. Most of the TPP's "WTO-extra" measures are non-binding and drafted in permissive language ("a party may"), rather than employing mandatory language ("a party shall"); accordingly, these measures should not be overly problematic to new joiners. In the key sector-specific market access chapters, these would have to be negotiated with the main supplier states, and whether an accommodation could be reached is an open question and could cause the merger to founder. Indeed, Scollay (2014) has argued that the level of ambition on market access is one of the biggest obstacles to overcome.

Scollay (2014) has identified several major issues with the TPP and RCEP memberships. The RCEP includes India, Cambodia, Laos, and Myanmar, which are not APEC members, as previously noted. If this scenario is to take place under the APEC framework, it will raise the following questions regarding whether the FTAAP would include these non-APEC members.

A key question is whether the FTAAP will develop inside APEC, as proclaimed in the Bogor Declaration. If the RCEP is to develop into the FTAAP within the APEC, then APEC must expand its membership to include the four non-APEC RCEP negotiating countries. It is an open question whether these four countries would wish to join APEC and also whether a consensus could be achieved within APEC to accept them. 
Moreover, common rules would have to be established where necessary, particularly regarding contentious issues such as the United States' "yarn forward" requirements for textile and apparel trade, which would pose similar difficulties for negotiators in an RCEP-TPP merger as were encountered with Vietnam in the TPP negotiations. Likewise, on liberalization of services trade, the TPP adopts the "negative list" approach, whereas the RCEP adopts a "positive list." On investment, the TPP's ISDS is highly controversial. IP rights protection, which is addressed in Chapter 11 in this book by Liu, is to be another contentious issue for the RCEP's non-TPP members and on which the United States would insist.

Politically, the merger of two established blocs with different lead countries is a big challenge. The lesson from the failure of the Free Trade Area of the Americas under which the United States and Brazil each tried to impose their own favorite FTA model is highly relevant. The political overtones of a merger or docking negotiation would color the entire process. For Beijing, Scenario 2 may be part of "China's dream," which TPP countries may not be keen on. In Chapter 3 in this book, Cheng and Lee will further elaborate on the complexity of this "China issue." For the TPP, it is part of the United States" "pivot to Asia," which many countries in the Asia Pacific, though not China, welcome as a long overdue US "rebalancing" to Asia.

As a commentary article in The Economist (2014) points out, "China and America each have their own plans for turning the Pacific into a giant free-trade area that both see as a test of their influence in the region and in the wider world." Indeed, in his State of the Union Address to Congress on January 20, 2015, President Obama said: "China wants to write the rules for the world's fastest-growing region. That would put our workers and businesses at a disadvantage. Why would we let that happen? We should write those rules. We should level the playing field" (White House, 2015) Meanwhile, US Defense Secretary Carter argued that "passing TPP is as important to me as another aircraft carrier" (Cooper, 2015).

Such statements set out the United States and China as rivals in mapping out the rules of the regional trade regime. ${ }^{19} \mathrm{~A}$ joint negotiation would necessarily have to be sensitive to these overtones. The most likely route would seem to be an extension of the path that the United States and China are currently on in the negotiation of bilateral agreements. For example, the US-China joint announcement on greenhouse gas emissions paves the way for enhanced cooperation in multilateral fora. Similarly, the conclusion of negotiations on a China-US Bilateral Investment Treaty would pave the way for regionalization of the terms of the agreement and, by extension, a follow-on China-US FTA would pave the way for 
a suitably framed FTAAP to serve as the successor to both the TPP and RCEP. The bilateral "Strategic and Economic Dialogue" between Beijing and Washington, though not able to resolve all disputes between these two great powers, is crucial to avoid mismanagement of the big-power relations. Whether or not this dialogue will lead to an equilibrium outcome in trade and investment in the future is unclear. Much will depend on the evolution of the Asia Pacific regional economy over the coming years, as this will change the facts on the ground, which ultimately dictate the outcome on treaties.

\section{Scenario 4: A New FTAAP Negotiation}

Using APEC to move towards a new FTAAP remains at least a theoretical possibility. While the United States originally championed this idea, it opposed a feasibility study proposed by China at the 2014 APEC Leaders meeting, chaired by China. One interpretation of the US opposition was that it would complicate its drive to conclude the TPP. Whether or not the United States will sustain its opposition now that the TPP has been inked remains to be seen.

For most practical intents and purposes, a new FTAAP negotiation faces no greater technical difficulties than the TPP's coming first accession round. Like the original TPP itself, the TPP enlargement negotiations will likely focus on new, non-liberalized bilateral relationships, with either no change or modest improvements on market access offers under existing FTAs to level them up to the best offers made. The rules would be the TPP rules and would likely contain commitments at least as strong as any existing FTA and, thus, largely make the latter redundant. That being said, just as the TPP did not formally subsume the existing agreements in the region (for example, the North American Free Trade Agreement, NAFTA, remains in place) and just as the RCEP will not disturb the existing ASEAN+1 agreements, the TPP enlargement will likely simply be layered upon the existing web of FTAs, leaving firms to choose the most advantageous treaty under which to trade. An FTAAP would be no different.

Compared to the very real prospect of TPP enlargement, a new APECwide FTAAP negotiation seems unlikely, since the circumstances under which the United States rejected the more lucrative FTAAP in favor of a TPP that promised it smaller gains, but greater control of the agenda, have not materially changed. Circumstances (both economic and political) may change the calculus of the key players, but at the moment there is no basis on which to hypothesize a change in tactics, which point to the TPP and the RCEP being promoted as independent tracks. 


\section{Scenario 5: The Mega Trade Blocs Remain; the FTAAP Remains the Long-Term Objective}

With the TPP signed, China has redoubled its efforts to conclude the RCEP. With its trade surplus and massive foreign currency reserves, it has the wherewithal to underwrite a deal. The United States is unlikely to be more welcoming to the RCEP than it was to the Asian Infrastructure Development Bank, but just as the latter initiative was able to move forward, so too would it appear that the RCEP can be concluded. While both agreements feature docking clauses, as noted by Schott et al. (2013), these have rarely been used, partly because new entrants erode preferences enjoyed by incumbent parties. This creates a hurdle to enlargement that can be sufficient to stall the expansion of membership of an agreement if the marginal gains from enlargement are not sufficient to cover the costs to incumbents. It is a realistic possibility, therefore, that the Asia Pacific will evolve with two competing blocs and other regional parties scrambling to protect their market positions by signing ad hoc FTAs. In this case, the Asian noodle bowl of FTAs will simply get more noodles.

In this scenario there will be two parallel mega trade blocs (the RCEP and the TPP) in the short to medium term. This will imply a multi-layer "freer trade" regime with different degrees of liberalization within each trade bloc and different rules of trade. With seven countries belonging to both blocs, these agreements will not be mutually exclusive; however, there will be no free trade between the two bloc leaders, at least in the intermediate stage. The creation of trade preferences by the two blocs will, however, work to restrict expansion of the membership in this scenario.

\section{The Road Ahead for the Asia Pacific Model of Regionalism}

Different from the functional approach of economic integration through trade and investment flows in the past, the road ahead for Asia Pacific economic integration needs to be more institutionalized to further strengthen production networks in the region. First, foreign investments must be protected to safeguard multinational corporations (MNCs) in host countries, and to assure the "competitive neutrality" of SOEs in competing with MNCs. This will require more formalized, rules-based institutional architectures, rather than administrative discretion, for dealing with MNCs.

Second, asymmetric market dependencies need to be balanced. To date, much of the trade volume of final goods produced in the Asia Pacific has been destined for the European Union and North America, whereas the inflows of capital investments and technological know-how mostly came from Organisation for Economic Co-operation and Development 
(OECD) countries and developed Asian countries. In general, Northeast Asia is more regionally integrated than most Southeast Asian and South Asian economies. As far as trade in final commodities is concerned, one can argue that ASEAN countries are probably more integrated with their non-ASEAN trading partners than with their ASEAN counterparts. And, within the emerging AEC, Cambodia, Laos, and Myanmar are less integrated than the rest of ASEAN. ${ }^{20}$ To generate more intra-regional trade will require a shift from "factory Asia" to "market Asia" trade patterns.

Third, given the generally low educational attainment and the relatively large proportion of unskilled labor in the workforce of many ASEAN countries, it is important to enhance not only capital investment but also technological transfer from developed countries, including from Northeast Asian economies such as Japan, Korea, and Taiwan, to increase the valueadded that developing countries contribute to global value chains (GVCs). Facilitating GVCs that enhance economic interdependence, narrowing income gaps between developed and developing Asian countries, and generating spillover effects from MNC technology transfer to local indigenous industries that narrow development gaps, will be more fruitful than simply pushing for a region-wide FTA at present.

Fourth, it is crucial that "non-discriminatory open regionalism" be pursued by all APEC members in the region, especially those outliers that are currently excluded from both the RCEP and TPP. ${ }^{21}$ Such regionalism will avoid market fragmentation by enabling all APEC members to connect without being marginalized.

It is worthwhile to point out that economic integration in the Asia Pacific is very different from that in Europe: the initial members of European Economic Community or even the European Common Market of 1986 were much more homogenous than either the RCEP or the TPP members in terms of economic development, culture and language, geography, and socio-political systems. The pathways from either the RCEP or the TPP towards an FTAAP will thus be significantly different from that followed by the European Union. Unlike the Atlantic Charter signed in 1941 and the North Atlantic Treaty Organization (NATO) in 1949, the common history of most Asia Pacific countries features rivalry of imperial powers and colonialism, ${ }^{22}$ and the only shared ideology in East Asia is nationalism, fueled by a sense of mutual historical grievances. And, as regards leadership of regional integration, the relationship between the United States and China is also different from that between post-war Germany and France when the initial European Economic Community was constructed.

The Asia Pacific will have its own unique model of regionalism with dynamic and multi-track economic integration. Its evolutionary process 
with gradual membership enlargement and incremental liberalization will generate a model of economic integration different from the European Union.

\subsection{THIS BOOK'S CONTRIBUTIONS}

This book has three parts. Part I, as well as this introductory chapter, includes two chapters that comment on the broader aspects of the US and Chinese roles in the TPP, the RCEP, and Asia Pacific regionalism.

In Chapter 2, Barfield delves deeply into the evolution of US policy towards the TPP and the interplay of domestic US politics with vital US strategic interests. Trade policy stands at the intersection of a nation's diplomatic and security strategies and its broad economic goals. Decisions regarding trade agreements, with both individual nations and groups thereof, are calculated to advance national strategic interests, as well as the fortunes of domestic corporations and workers. Political scientists also refer to trade policy-making as a two-level game: national leaders strive to forge an internal consensus on US trade negotiating goals and then must further attempt to achieve those goals at the international level. Utilizing these organizing themes, Barfield describes and analyzes the United States' evolving role in Asia over the past three decades, where the juxtaposition of economic and security goals has propelled its actions and priorities. He concludes that the TPP is indispensable to the United States' ability to maintain a central leadership role in Asia in the twenty-first century.

In Chapter 3, Cheng and Lee examine how China and Taiwan may join the TPP. Initially denouncing it as essentially a US ploy to "pivot back" to Asia, China has taken a number of countermeasures, including accelerating its pursuit of bilateral FTAs, actively promoting the RCEP, and, arguably, initiating a few new plurilateral development banks. Since 2013, however, China has been assessing whether or not to participate in the TPP. Cheng and Lee suggest that it will not yet be ready to submit its bid for membership when the TPP opens up, but instead is likely to conclude the RCEP and then push for a TPP-RCEP merger. Meanwhile China is likely to expand rather than contract those countermeasures to offset the geostrategic and geo-economic effects that the TPP might entail for China.

Lagging behind its trade competitor South Korea, in pursuit of FTAs, Taiwan has been doing its utmost to gain TPP membership, which is nominally open to all APEC members. The APEC and WTO precedents, including participation in the TiSA negotiations, suggest that Taiwan might join 
multinational economic clubs simultaneously with, immediately after, or even before China's admission. Accordingly, if Taiwan has the political will to forge a winning political coalition internally and the astuteness to finesse China externally, there would seem to be no insuperable barrier to Taiwan joining the TPP before China. Taiwan seems readier to do so and the geostrategic dynamics in East Asia are not as harsh to Taiwan as they used to be. Both domestic and international statecraft is thus the key to Taiwan's TPP accession.

Part II of this book regards the enlargement of TPP membership as a roadmap towards mega regionalism. The chapters herein focus on the quantitative assessment of the benefits of membership enlargement for both the incumbent TPP members, as well as for new members and the region as a whole.

In Chapter 4, Ciuriak and Xiao address how the founding 12 TPP members (the TPP12) will be affected by membership expansion, using Taiwan's admission as a case study. They show that this would expand the overall economic gains for the TPP12 considerably, though they would have to give up preferential gains made at Taiwan's expense. Accordingly, the path to an FTAAP through the expansion of existing FTAs faces the challenge of overcoming potential resistance from existing TPP members who might stand to lose rather than gain from the expansion.

In Chapter 5, Chow compares the impacts of four prospective members Indonesia, the Philippines, Taiwan, and Thailand - on the US economy by assessing their respective interdependency, trade complementarity with the United States, and relative contributions to the global value-added in US exports. He uses a computable general equilibrium (CGE) model to show that the TPP12 will benefit from Taiwan's inclusion. He further analyzes the comparative advantage of US services trade and the potential opportunity for the United States to exploit those markets of these four prospective new members.

In Chapter 6, Ciuriak and Xiao focus on the impact of Taiwan's TPP accession on the US economy. They examine the issue of accession strategies of prospective members, using the challenges that Taiwan will face as a test case. In Chapter 7, Chow and Hsu present a CGE model simulation on an expanded TPP membership to include Indonesia, Korea, the Philippines, Thailand, China, and Taiwan. They find that there is an incremental welfare gain, GDP and trade growth as TPP membership increases. This chapter assesses the regional economic outlook and Scenario 1 discussed above.

Part III, the final part of this book, addresses issues related to sectoral liberalization. The TPP has 30 chapters, which cover numerous substantive matters. Constraints on the size of this volume require that only selected issues are addressed in detail. 
In Chapter 8, Tuan and Somwaru examine the liberalization of agricultural trade under the TPP, employing a partial equilibrium approach to demonstrate the differences in impact on agricultural commodity trade, production, and consumption under a TPP with and without China, while abolishing all import tariffs and tariff-rate quotas.

In Chapter 9, Chen Chiu assesses the TPP's impact on the pharmaceutical industry's ability to achieve learning, a catch-up platform, and innovation of industrial cooperation between import and export countries, and job creation opportunities. The literature review provides theoretical and empirical evidence on pharmaceutical pricing, patent protection, trade-induced FDI, and profit earnings between pharmaceutical export and import countries. The rising attention to cost containment is also addressed. The chapter presents a statistical comparison of medical and pharmaceutical performance in Taiwan, which is one of the first countries in the world with a mandated National Health Insurance regime and single insurer (put in place in 1995). The market penetration of new drugs through institutional design can contribute to pharmaceutical innovation, which can lead to future international collaborations on compound formulas for herbal medicines, creating new market mechanism in the region.

In Chapter 10, Thompson applies a specific factors model to analyze the potential income redistribution inside TPP countries due to increased trade and the changing prices of services, finding that there is a substantial income redistribution between three labor skill groups and industrial capital in the simulations. He argues that tax policies should anticipate rather than react to the pending income redistribution inside the TPP.

Finally, in Chapter 11, Liu analyzes the flexibility of IP rights protection under the TPP, based on an advanced version of the TPP IP chapter. She shows how the United States has been aggressively seeking stronger and less flexible IP right provisions than those included in existing international IP agreements, and argues that accepting higher standards of IP protections may not only be unnecessary in promoting investment and economic growth, but can also result in negative impacts on development due to price increases. Similarly, the unwillingness of the TPP members to truly balance public health needs with an aggressive patent agenda also puts the future of the TPP at risk. She argues that the TPP should pursue unreasonable "TRIPS-plus" (Trade-Related Aspects of Intellectual Property Rights) provisions and should balance the public interests of the TPP economies with IP protection. 


\subsection{A NEW AGE DAWNS FOR ASIA PACIFIC REGIONALISM}

The TPP is a milestone and possibly a watershed agreement for Asia Pacific economic regionalism. Both in its own right and through the impetus it will give to the conclusion of the parallel RCEP negotiations, it marks the emergence of a complex new architecture for regional trade and investment. This book provides an early analysis of the immediate implications for the accession of new members to these two regional agreements, considers the economic and political factors that are likely to shape these accessions, and outlines possible onward paths towards a seamless future regime for free and open trade in the Asia Pacific region.

\section{NOTES}

* The author would like to express his gratitude to several contributors to this book for very constructive discussions on an early version of this chapter. I would like to thank Dan Ciuriak for his editorial assistance and invaluable suggestions. However, the usual caveats apply.

1. Japan made investments in Korea, Taiwan and other East Asian countries which are considered as the first tier of the newly industrialized countries (NICs) prior to the Plaza Accord. After the yen appreciation beginning in 1985, Japan accelerated its outward FDI by switching labor-intensive sectors from the first tier of the NICs to Southeast Asia as the second tier of the NICs.

2. The RCEP's developed countries are more interested in investment, economic and technical cooperation, intellectual property, market competition, and dispute settlement than liberalization of goods.

3. Due to Brunei joining the negotiations late, its $\mathrm{P} 4$ commitments were implemented on a delayed basis compared to those of the other three parties.

4. See Elms (2009) and Gao (2009) for detailed discussions.

5. Brunei's services commitments were not developed when the agreement came into force. These were to have been filed within two years, but were not. See Gao (2009).

6. See WTO (2008). The agreement was notified by the parties to the WTO on 18 May 2007 under Article XXIV:7(a) of the GATT 1994 and the Understanding on the Interpretation of Article XXIV of GATT 1994 as an agreement establishing a free-trade area (WTO, 2008) and under GATS Article V:7(a) as an agreement providing for the liberalization of trade in services within the meaning of Article V of the GATS.

7. Gao (2009), citing Estevadeordal et al. (2009).

8. Gao (2009), citing the comparative analysis by Fink and Molinuevo (2007); and Baldwin (2006).

9. Gao (2009), citing the detailed analysis by Teh et al. (2009) of the range of approaches adopted in extant regional trade agreements. Notably, ANZSCEP (Singapore and New Zealand) raised the de minimis dumping margin from 2 percent to 5 percent and the margin of negligible imports from 3 percent to 5 percent. While the P4 included this provision, it did so only for Singapore-New Zealand trade (Gao, 2009: 16).

10. The inclusion of ISDS was one of the most contentious issues in the negotiation and could only be agreed by respecting Australia's wish to exclude tobacco companies from access to the mechanism. This reflected the ISDS challenge mounted by the US firm Philip Morris to Australia's plain packaging regulations for tobacco products. 
11. APEC formally started discussing the concept of an FTAAP at its summit in 2006 in Hanoi. In the Leaders' Declaration in 2010, it says: "We will take concrete steps toward realization of a Free Trade Area of the Asia Pacific (FTAAP), which is a major instrument to further APEC's regional economic integration agenda" (APEC, 2010).

12. Since the first goal of trade liberalization among developed countries failed, APEC announced at its 2010 meeting in Yokohama that the TPP, as well as the ASEAN +6 and ASEAN+3, would act as pathways to an FTAAP to fulfil the Bogor Declaration.

13. One can reasonably argue that, in spite of its ASEAN centrality, the RCEP is a Chinaled trade bloc, which prioritizes the liberalization of trade in commodities. The TPP, meanwhile, is clearly a US-led trade bloc, whose agenda is dominated by US promotion of its own commercial standards as the international norm.

14. At present, APEC membership is a prerequisite to join the TPP. Colombia was interested in joining the TPP, but was rejected because it is not an APEC member.

15. Korea's attitude towards the TPP is well analyzed by Schott and Cimino (2014), while its FTA policy is described by Cheong (2014).

16. The EurAseEC includes Belarus, Russia, Kazakhstan, the Kyrgyz Republic, and Tajikistan.

17. Dent (2013: 981) argues that, from Europe's experience over the past three decades, "comprehensive regional economic integration can be truly achieved only when peripheral or weaker economies are empowered to participate in regional economic integration process."

18. Contentious liberalization of agricultural products is not limited to these five major products: in the US-New Zealand FTA negotiations, the United States also had major protectionist lobbies for cotton, sugar, and dairy against New Zealand.

19. These statements should be taken in context. For the most part, the technical rules of trade are developed by subject-matter experts working in many international organizations, specializing in particular issues such as customs procedures or ROOs, taking into account accumulated experience with problems that have been encountered and legal decisions that have been handed down by various courts, including WTO dispute settlement cases that may address the interpretation of specific texts. The technical experts advising the parties in a WTO, TPP, or RCEP also sit on international committees in the World Customs Organization, international ROOs expert groups, and other similar fora; they draw on the same shared body of experience and eventually settle on the same standard language, which becomes "boilerplate" text in FTAs. There is, in other words, an acquis in the art of FTA writing. Thus, while there are differences in FTA rules, there is also much in common.

20. Note that Myanmar is engaged in economic and political structural reforms and opening up its domestic market.

21. Hong Kong, Taiwan, Papua New Guinea, and Russia are these excluded APEC members, although Russia has its own Eurasian vision of economic integration as previously noted.

22. Thailand is probably the only country that has not been colonized.

\section{REFERENCES}

APEC. 1994. 1994 Leaders' Declaration. Bogor: APEC.

APEC. 2010. 2010 Leaders' Declaration. Yokohama: APEC.

Baldwin, R. 2006. "Multilateralising Regionalism: Spaghetti Bowls as Building

Blocs on the Path to Global Free Trade." World Economy 29(11): 1451-1518.

Capling, A. 2009. "Multilateralising PTAs in the Asia-Pacific Region: A Comparison of the ASEAN-Australia-NZ FTA and the P4 Agreement." Paper prepared for the Asia-Pacific Trade Economists' Conference, ARTNeT, UNESCAP, and UNDP, Bangkok, 2-3 November. 
Cheng, T.-J. and P.C.Y. Chow. 2014. "The TPP and the Pivot: Economic and Security Nexus." In P. Chow (ed.), The US Strategic Pivot to Asia and Cross-Strait Relations: Economic and Security Dynamics, New York: Palgrave Macmillan, pp. 113-134.

Cheong, I. 2014. "South Korea's Recent FTA Policy: A Personal Viewpoint." In T. Guogiang and P.A. Petri (eds), New Directions in Asia-Pacific Economic Integration, Honolulu: East-West Center, pp. 138-149.

Ciuriak, D. 2010. "East Asian FTAs and Their Implications for Economic Welfare and Global Trade: The Domino Theory Revisited." Working Paper. Available at http://ssrn.com/abstract $=1692448$.

Cooper, H. 2015. "US Defense Secretary Supports Trade Deal With Asia." New York Times, April 6.

Dent, C.M. 2013. "Paths Ahead for East Asia and Asia-Pacific Regionalism." International Affairs 89(4): 963-985.

Elms, D.K. 2009. "From the P4 to the TPP: Explaining Expansion Interests in the Asia-Pacific." Paper prepared for the Asia-Pacific Trade Economists' Conference, ARTNeT, UNESCAP, and UNDP, Bangkok, 2-3 November.

Elms, D.K. and C.L. Lim. 2012. "The Trans-Pacific Partnership Agreement (TPP) Negotiations: Overview and Prospects.” RSIS Working Paper 232, February 21.

Estevadeordal, A., J. Harris and K. Suominen. 2009. "Multilateralising Preferential Rules of Origin around the World." IDB Working Paper Series 137.

Fink, C. and M. Molinuevo. 2007. "East Asian Free Trade Agreements in Services: Roaring Tigers or Timid Pandas?" World Bank Policy Research Paper 40175.

Gao, H. 2009. "The Trans-Pacific Strategic Economic Partnership Agreement: High Standard or Missed Opportunity?" Paper prepared for the Asia-Pacific Trade Economists' Conference, ARTNeT, UNESCAP, and UNDP, Bangkok, 2-3 November.

Hamanaka, S. 2014. "Trans-Pacific Partnership versus Regional Comprehensive Economic Partnership: Control of Membership and Agenda Setting." Asia Development Bank Working Paper Series on Regional Economic Integration 146.

Harris, T. 2015. "The Next Steps for Japan on the Road to the Trans-Pacific Partnership." Sasakawa Peace Foundation, October 27.

Hsu, B.-X. 2013. "The Impacts of TPP Membership on Macro Economy and Industries in Taiwan." Outlook of Asia Pacific Economic Integration 36(2): 26-36 (in Chinese).

Menon, J. 2014. "From Spaghetti Bowl to Jigsaw Puzzle? Addressing the Disarray in the World Trade System.” Asia Development Bank Working Paper Series on Regional Economic Integration 140.

Petri, P., M.G. Plummer and F. Zhai. 2011 [2013]. "The Trans-Pacific Partnership Integration: A Quantitative Assessment." East-West Center Working Paper 119, updated 2013.

Schott, J.J. and C. Cimino. 2014. "Should Korea Join the Trans-Pacific Partnership?" Policy Brief PB14-22, Peterson Institute for International Economics.

Schott, J.J., B. Kotschwar and J. Muir. 2013. "Understanding the Trans-Pacific Partnership." Policy Analyses in International Economics 99, Peterson Institute for International Economics.

Scollay, R. 2014. "The TPP and RCEP: Prospect for Convergence." In T. Guogiang and P.A. Petri (eds), New Directions in Asia-Pacific Economic Integration, Honolulu: East-West Center, pp. 235-245. 
Teh, R., T. Prusa and M. Budetta. 2009. "Trade Remedy Provisions in Regional Trade Agreements." In A. Estevadeordal, K. Suominen and R. Teh (eds), Regional Rules in the Global Trading System, Cambridge: Cambridge University Press, pp. 166-249.

The Economist. 2014. "The Pacific Age." November 15.

United States Trade Representative (USTR). 2014. "Trans-Pacific Partnership Trade Ministers' Report to Leaders." Press Release, November 10. https:// ustr.gov/about-us/policy-offices/press-office/press-releases/2014/November/ Trans-Pacific-Partnership-Trade-Ministers-Report-to-Leaders.

White House. 2015. "Remarks of President Barack Obama - As Prepared for Delivery State of the Union Address." WhiteHouse.gov, January 20. https://www. whitehouse.gov/the-press-office/2015/01/20/remarks-president-barack-obamaprepared-delivery-state-union-address.

WTO. 2008. "Consideration of the Trans-Pacific Strategic Economic Partnership Agreement between Brunei Darussalam, Chile, New Zealand and Singapore, Goods and Services." Note on the Meeting of September 18-19, WT/ REG229/M/1, October 27.

Zhang, J. 2014. "How Far Away is China from the TPP?" In T. Guogiang and P.A. Petri (eds), New Directions in Asia-Pacific Economic Integration, Honolulu: East-West Center, pp. 66-77. 